\title{
Comparative Analysis of the Tax Burden on Innovative and Non-Innovative Sectors of Manufacturing in Russia
}

\author{
Vladislav Spitsin \\ Department of Management \\ Tomsk Polytechnic University \\ Tomsk, Russia \\ Spitsin_vv@mail.ru \\ Aleksandr Mikhalchuk \\ Department of Higher Mathematics \\ Tomsk Polytechnic University \\ Tomsk, Russia \\ Kristina Bannova \\ Department of Management \\ Tomsk Polytechnic University \\ Tomsk, Russia \\ bannovaka@yandex.ru
}

\author{
Natalia Pokrovskaya \\ Saint Petersburg State University \\ St. Petersburg, Russia \\ Darya Novoseltseva \\ Tomsk Polytechnic University \\ Tomsk, Russia \\ Ilya Gumennikov \\ Tomsk Polytechnic University \\ Tomsk, Russia \\ Lubov Spitsina \\ Tomsk Polytechnic University \\ Tomsk, Russia
}

Department of Credit Theory and Financial Management

\begin{abstract}
The purpose of this paper is a comparative analysis of the tax burden on innovative and non-innovative sectors of manufacturing industry in Russia. We analyze the differences between innovative subsection DL "Manufacture of electrical and optical equipment" and non-innovative section D "Manufacturing" at the Russian regional level using methods of statistical analysis. We found that the level of the tax burden on innovative subsection DL is not lower than on non-innovative section D. It was not discovered though a stimulating effect of taxation on innovative development. Cluster analysis confirmed statistically significant differences in the level of tax burden on subsection DL by regions. We identified several regions with low tax burden. Tax incentives can be used to stimulate industrial development in these territories.
\end{abstract}

Keywords - tax burden; innovative development; statistical analysis; manufacture of electrical and optical equipment; manufacturing industry; Russian regions

\section{INTRODUCTION}

Many current scientific studies have questioned the effect of the tax burden level on economic and innovative development of certain countries and territories. In economic studies, scientists conduct extensive researches on impact of tax rates, tax reform, progressive taxation scales, preferential taxation on enterprise performance and economic growth $[1,2$, 3 , 4]. Based on revealed regularities, scientists develop proposals to improve the taxation systems in individual countries and territories. The effect of taxation on the innovative development is studied in [5, 6]. Currently the

This research was financially supported by Russian Foundation for Basic Research (RFBR) in the frame of the project for scientific studies (Mathematical modeling of the formation activities consolidated group of taxpayers to harmonize the interests of the state and taxpayers), project No. 16-36-00184. effect of tax incentives to encourage investment in research and development are being studied intensively. Scientists confirm the effect of tax benefits on R \& D investment. However, it is noted, that the level of such influence is lower than expected. In the works of Russian scientists the problem of the tax burden influence on economic and innovative development, including on the basis of statistical data is also studied [7, 8, 9, 10]. Note, however, that all these studies are carried out at the level of individual businesses, economy sector or regional level. The study of the tax burden across sectors and regions at the same time has not been realized yet.

In this paper we solve this problem by conducting the analysis broken down by regions, sectors and types of taxes. The purpose of our study is to compare the tax burden of innovative subsection DL and manufacturing sector (section D) and to implement cluster analysis of tax burden on subsection DL at the level of Russian regions.

The object of research is subsection DL "Manufacture of electrical and optical equipment" (subsection DL according to the NACE Rev. 1.1. or C26+C27 according to the NACE Rev. 2, Eurostat classification of economic activities). This subsection is one of the innovation-active subsections of manufacturing industry in Russia. It is also characterized by high social indicators such as employment rate and payroll fund. As an object for comparison section D "Manufacturing" is selected. It should be noted that a significant portion of D section's shipping, accounted for resource-related subsections, characterized by low innovation activity (DJ, DF). The 
research period is 2013 year. The information base includes data of tax statistics [11] and economic statistics [12] at the level of Russia and its regions. We apply the following methods of analysis: variance and cluster analysis and use software product "Statistics" for calculations [13, 14, 15, 16].

\section{RESEARCH METHODOLOGY}

Research is conducted at the level of Russian regions. The sample of subsection DL formed from the 30 regions with the largest volumes of products shipped in 2013 and sorted in descending order. The sample of section $\mathrm{D}$ is built for comparison a similar way. The indicators system for the study is presented in Table 1.

On the basis of tax and economic statistics for 2013, tax burden in a cut of regions and types of taxes was calculated. Calculation of indicators №1-7 and №10 was carried out by dividing the amount of the corresponding tax paid on volume of shipped products. For indicators №8 and №9 taxes into respective budgets (excluding excise taxes and insurance premiums) were preliminarily assessed:

- Federal budget. The corresponding part of income tax (tax statistics data is available), VAT and all other federal taxes;

- Regional and Local budgets. Part of income tax, personal income tax, regional and local taxes.

The obtained values were divided by the volume of shipped products.

It should be noted that these tax statistics does not provide information about the amount of the paid social insurance tax payments by type of economic activity and regions of Russia.

\section{RESUlts OF StATISTICAL ANALYSIS}

\section{A. The level of tax burden on the subsection DL broken down} by regions

The level of tax burden on the subsection DL broken down by regions and types of taxes is represented on Fig. 1. Here and below, the numbering of indicators in the figures and in the text is given in accordance with their numbering in the Table 1.

Calculations show the significant differentiation of the tax burden by Russian regions. We identified several regions with lower tax burden on subsection DL. These regions are: the Kaluga region, Kaliningrad region, Pskov region, Ulyanovsk region. Tax incentives can be used to stimulate industrial development on these territories.

\section{B. Comparison of the mean values of the tax burden on subsection DL and on section D (analysis of variance)}

Using analysis of variance, we compared the mean values of the tax burden on subsection DL and on section D for two samples of regions. The results of comparison are represented on Fig. 2.

In this case, the parametric F-test and Kruskal-Wallis test show that the differences between DL and D are highly significant (at $\mathrm{p}<0.0005$ ) for the indicators №1, 3, 4, 8, 9; statistically significant for №5, $7(0,05>\mathrm{p}>0,005)$; weakly significant for №2 $(0,105>\mathrm{p}>0,05)$ and not significant for №6, $10(\mathrm{p}>0,105)$.

TABLE I. The System Of INDICATORS For ThE ANALySIS OF TAX BURDEN OF SUBSECTION DL

\begin{tabular}{|l|l|}
\hline № & \multicolumn{1}{|c|}{ Indicators } \\
\hline & $\begin{array}{l}\text { Total tax revenues (excluding excise taxes and insurance } \\
\text { premiums) (total taxes) / shipped goods }\end{array}$ \\
\hline 2 & Income tax (profit tax) / shipped goods \\
\hline 3 & Personal income tax (PIT) / shipped goods \\
\hline 4 & Value added tax (VAT) / shipped goods \\
\hline 5 & Regional taxes / shipped goods \\
\hline 6 & Local taxes / shipped goods \\
\hline 7 & $\begin{array}{l}\text { Taxes collected in accordance with the special regimes (Special } \\
\text { regimes) / shipped goods }\end{array}$ \\
\hline 8 & Taxes into federal budget (Federal budget) / shipped goods \\
\hline 9 & $\begin{array}{l}\text { Taxes into regional and local budgets (Regional and local } \\
\text { budgets) / shipped goods }\end{array}$ \\
\hline 10 & $\begin{array}{l}\text { Total tax revenues (including excise taxes, but excluding } \\
\text { insurance payments) / shipped products }\end{array}$ \\
\hline
\end{tabular}

${ }^{\text {a. }}$ In regard to the personal income tax (PIT) we note the following. The PIT is paid from the salary of the employee and has no direct effect to company's expenses. However, we do not exclude it from the analysis, because businesses are forced to take PIT into account in determining salaries, particularly in sectors with low wages.

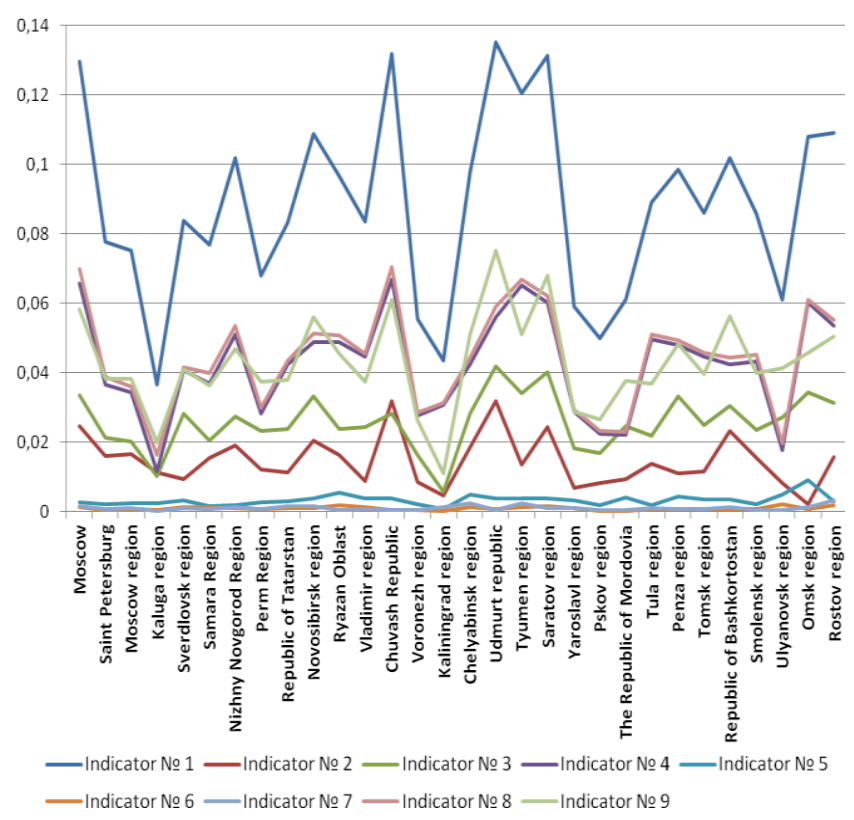

Fig. 1. The level of tax burden on the subsection DL broken down by regions and types of taxes 


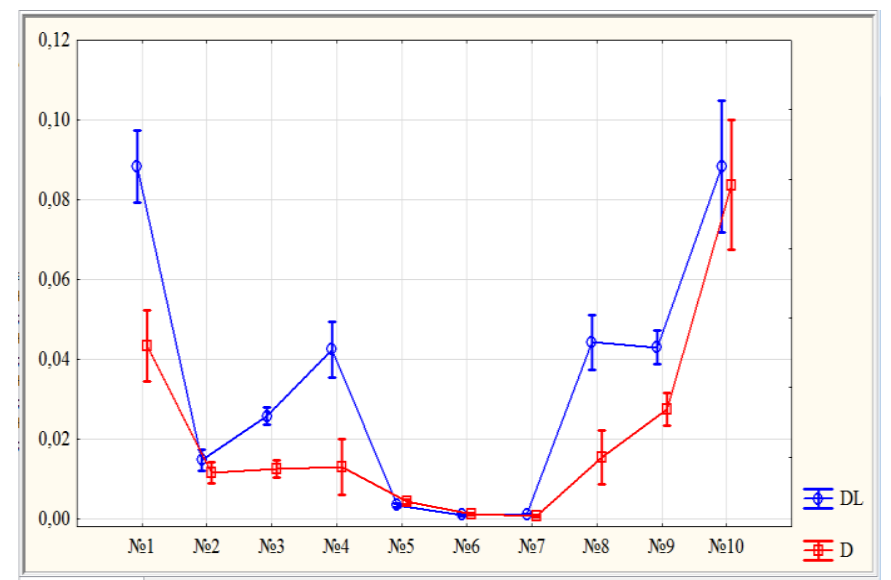

Fig. 2. Mean values of indicators for the subsection DL and section D with $95 \%$ confidence intervals

For indicators №1 (Total tax revenues (excluding excise taxes and insurance premiums)), №3 (PIT), №4 (VAT), №8 (Taxes into federal budget) and №9 (Taxes into regional and local budgets) were revealed highly significant statistical differences in the average tax burdens. Moreover, for all these types of taxes the tax burden of innovative subsection DL is much higher than in the manufacturing industry as a whole (Fig. 2). Average values are comparable in size only for indicator №10.

Thus, at the level of innovative subsection DL we have not observed any signs of tax incentives for innovation activity. Tax incentives in certain regions (Kaluga region, Kaliningrad region, etc.) does not solve the problem at the sector level, where the tax burden (excluding excise taxes) is higher than the one of manufacturing industry as a whole.

\section{Cluster analysis of regions.}

The regions were clustered by the indicators №8 and №9. Using the methods of tree clustering (with the unit rule of Ward's method) and k-means clustering we have combined the 30 regions in the 6 clusters. Graphically, clustering results are illustrated in the scatter plot (Fig. 3). In this Figure the number of regions in each cluster was indicated in parentheses. Table 2 shows distribution of Russian regions by clusters.

Parametric analysis of variance showed that clusters in their totality differ highly significant (significance level of $p$ $<0,0005$ ) for indicators №8 and №9 (Table 3).

According to Table 4 (significance levels for multiple comparisons), there is no uniform (not significantly different) cluster group on set of indicators №8 and №9. For example, clusters $\mathrm{C} 2$ and $\mathrm{C} 3$ are insignificantly different by the indicator №9, but they differ highly significant by the indicator №8.

The smallness of the clusters sample assumes to control these results by rank Kruskal-Wallis test. The Kruskal-Wallis test smoothes out the differences for clusters in their totality to strongly significant $(0,005>\mathrm{p}>0,0005)$. At the same time, the difference between $\mathrm{C} 2$ and $\mathrm{C} 3$ by indicator №8 is smoothed to a statistically significant level $(0.05>\mathrm{p} \approx 0.007>0.005)$.

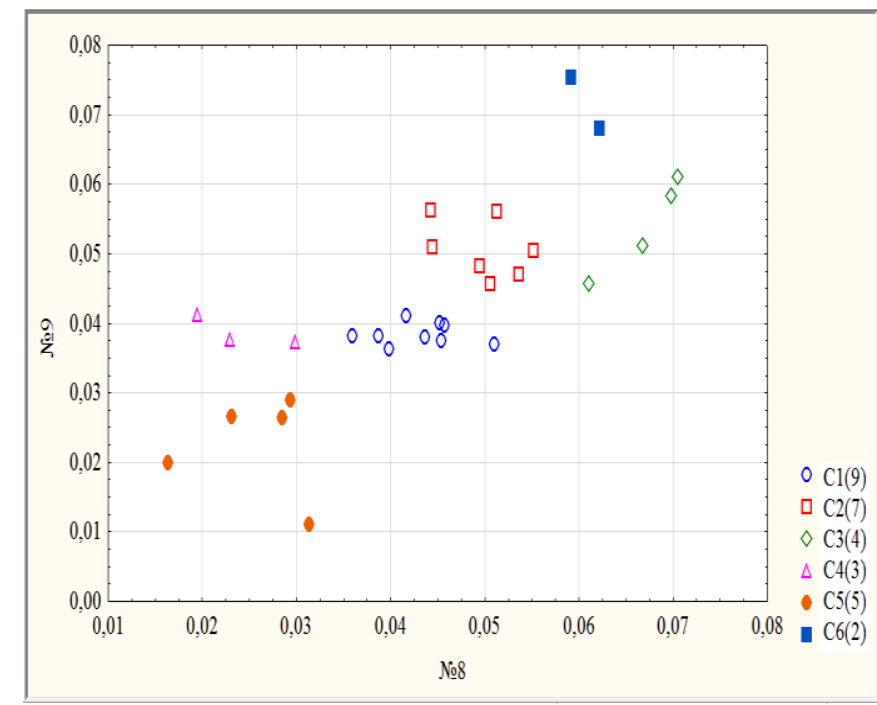

Fig. 3. Scattering of regions clusters by the indicators №8 and №9

TABLE II. DISTRIBUtION OF RUSSIAN REGIONS By CLUSTERS

\begin{tabular}{|c|c|c|c|}
\hline \multirow[t]{2}{*}{ Region } & \multicolumn{2}{|c|}{ Values of indicators } & \multirow[t]{2}{*}{ Cluster } \\
\hline & №8 & №99 & \\
\hline Vladimir region & 0,0454 & 0,0375 & $\mathrm{C} 1$ \\
\hline St. Petersburg & 0,0387 & 0,0382 & $\mathrm{C} 1$ \\
\hline Moscow region & 0,0359 & 0,0381 & $\mathrm{C} 1$ \\
\hline Republic Of Tatarstan & 0,0437 & 0,0379 & $\mathrm{C} 1$ \\
\hline Samara Region & 0,0399 & 0,0362 & $\mathrm{C} 1$ \\
\hline Sverdlovsk region & 0,0417 & 0,0411 & $\mathrm{C} 1$ \\
\hline Smolensk region & 0,0452 & 0,0399 & $\mathrm{C} 1$ \\
\hline Tomsk region & 0,0457 & 0,0396 & $\mathrm{C} 1$ \\
\hline Tula region & 0,0510 & 0,0369 & $\mathrm{C} 1$ \\
\hline Nizhny Novgorod Region & 0,0536 & 0,0470 & $\mathrm{C} 2$ \\
\hline Novosibirsk region & 0,0513 & 0,0561 & $\mathrm{C} 2$ \\
\hline Penza region & 0,0494 & 0,0481 & $\mathrm{C} 2$ \\
\hline Republic Of Bashkortostan & 0,0442 & 0,0563 & $\mathrm{C} 2$ \\
\hline Rostov region & 0,0552 & 0,0505 & $\mathrm{C} 2$ \\
\hline Ryazan region & 0,0506 & 0,0456 & $\mathrm{C} 2$ \\
\hline Chelyabinsk region & 0,0444 & 0,0510 & $\mathrm{C} 2$ \\
\hline Moscow & 0,0698 & 0,0583 & $\mathrm{C} 3$ \\
\hline Omsk region & 0,0610 & 0,0457 & $\mathrm{C} 3$ \\
\hline Tyumen region & 0,0668 & 0,0510 & $\mathrm{C} 3$ \\
\hline Chuvash region & 0,0705 & 0,0610 & $\mathrm{C} 3$ \\
\hline Perm Region & 0,0298 & 0,0373 & $\mathrm{C} 4$ \\
\hline Mordovia region & 0,0230 & 0,0376 & $\mathrm{C} 4$ \\
\hline Ulyanovsk region & 0,0195 & 0,0412 & $\mathrm{C} 4$ \\
\hline Voronezh region & 0,0285 & 0,0264 & $\mathrm{C} 5$ \\
\hline Kaliningrad region & 0,0314 & 0,0110 & $\mathrm{C} 5$ \\
\hline Kaluga region & 0,0163 & 0,0199 & $\mathrm{C5}$ \\
\hline Pskov region & 0,0232 & 0,0265 & $\mathrm{C} 5$ \\
\hline Yaroslavl region & 0,0294 & 0,0289 & $\mathrm{C} 5$ \\
\hline Saratov region & 0,0622 & 0,0680 & C6 \\
\hline Udmurt region & 0,0592 & 0,0753 & C6 \\
\hline
\end{tabular}

TABLE III. VARIANCE ANALysis OF THE REGIONS CLUSTERING

\begin{tabular}{|l|l|l|l|l|c|c|}
\hline Indicator & Between SS & df & Within SS & df & F & p \\
\hline №8 & 26,270 & 5 & 2,730 & 24 & 46,198 & 0,0000 \\
\hline №9 & 26,598 & 5 & 2,402 & 24 & 53,153 & 0,0000 \\
\hline
\end{tabular}

TABLE IV. Results OF F-Test For Multiple COMPARISONS OF CLUSTERS

\begin{tabular}{|l|c|c|c|c|c|c|c|}
\hline Indicator & & C1 & C2 & C3 & C4 & C5 & C6 \\
\hline №8 & C1 & & 0,008 & 0,000 & 0,000 & 0,000 & 0,000 \\
\hline
\end{tabular}




\begin{tabular}{|c|c|c|c|c|c|c|c|}
\hline & $\mathrm{C} 2$ & 0,008 & & 0,000 & 0,000 & 0,000 & 0,008 \\
\hline & C3 & 0,000 & 0,000 & & 0,000 & 0,000 & 0,133 \\
\hline & $\mathrm{C4}$ & 0,000 & 0,000 & 0,000 & & 0,634 & 0,000 \\
\hline & $\mathrm{C} 5$ & 0,000 & 0,000 & 0,000 & 0,634 & & 0,000 \\
\hline & C6 & 0,000 & 0,008 & 0,133 & 0,000 & 0,000 & \\
\hline \multirow[t]{7}{*}{ №9 } & & $\mathrm{C} 1$ & $\mathrm{C} 2$ & C3 & $\mathrm{C} 4$ & $\mathrm{C} 5$ & C6 \\
\hline & $\mathrm{Cl}$ & & 0,000 & 0,000 & 0,921 & 0,000 & 0,000 \\
\hline & $\mathrm{C} 2$ & 0,000 & & 0,259 & 0,001 & 0,000 & 0,000 \\
\hline & C3 & 0,000 & 0,259 & & 0,000 & 0,000 & 0,000 \\
\hline & $\mathrm{C} 4$ & 0,921 & 0,001 & 0,000 & & 0,000 & 0,000 \\
\hline & $\mathrm{C} 5$ & 0,000 & 0,000 & 0,000 & 0,000 & & 0,000 \\
\hline & C6 & 0,000 & 0,000 & 0,000 & 0,000 & 0,000 & \\
\hline
\end{tabular}

Clustering of regions is an important supplement to other methods of statistical analysis, in particular, analysis of variance. ANOVA allows exploring differences in rates for the whole a set of regions. Clustering provides the opportunity to explore the differences in rates at the level of certain regions or groups of regions (clusters) and identify the regions or groups of regions with atypical behavior. In this case, we find clusters C4 (including 3 regions) and C5 (5 regions), which are characterized by low tax burden.

\section{CONCLUSIONS}

The conducted analysis allows us to make the following conclusions.

1. Significant differentiation of the tax burden subsection DL by regions and types of taxes is revealed. Some regions are characterized by a lower level of tax burden, which suggests the presence in these territories of tax benefits aimed at promoting industrial development.

2. Analysis of variance at the regional level of Russia showed that the level of tax burden (excluding excise taxes) of innovative subsection DL is higher than non-innovative section D. Considering the excise, tax burden of DL and D is statistically insignificant. Thus, it does not occur a stimulation of the development of innovative subsection DL due to taxes in Russia.

3. Cluster analysis confirmed statistically significant differences in the tax burden level of subsection DL by regions. A number of regions have a low tax burden. These peculiarities require further in-depth analysis of the behavior of these regions, both at the level of the tax legislation, as well as by assessing the impact of the low tax burden on DL-enterprises development.

\section{ACKNOWLEDGEMENT}

This paper was written with the financial support from Russian Foundation for Basic Research (RFBR), scientific project No. 16-36-00184 "Mathematical modeling of the formation activities consolidated group of taxpayers to harmonize the interests of the state and taxpayers"

\section{REFERENCES}

[1] N. Gemmell, R. Kneller, and I. Sanz, "The growth effects of tax rates in the OECD," Canadian Journal of Economics/Revue canadienne d'économique, vol. 47, no. 4, pp. 1217-1255, Nov. 2014. Available at: http://dx.doi.org/10.1111/caje.12105

[2] Y. Liu and J. Martinez-Vazquez, "Growth-Inequality Tradeoff in the Design of Tax Structure: Evidence from a Large Panel of Countries,' Pacific Economic Review, vol. 20, no. 2, pp. 323-345, May 2015. Available at: http://dx.doi.org/10.1111/1468-0106.12109
[3] B. Atems, "Another look at tax policy and state economic growth: The long-run and short-run of it," Economics Letters, vol. 127, pp. 64-67, Feb. 2015. Available at: http://dx.doi.org/10.1016/j.econlet.2014.12.035

[4] K. Zeng, S. Li, and Q. Li, "The Impact of Economic Growth and Tax Reform on Tax Revenue and Structure: Evidence from China Experience," Modern Economy, vol. 04, no. 12, pp. 839-851, 2013. Available at: http://dx.doi.org/10.4236/me.2013.412091

[5] Z. Liu, "The research tax credit in the policy mix for innovation: the French case," Journal of Innovation Economics, vol. 12, no. 2, p. 199, 2013. Available from: http://dx.doi.org/10.3917/jie.012.0199

[6] S. Fabiani and R. Sbragia, "Tax Incentives for Technological Business Innovation in Brazil: The Use of the Good Law - Lei do Bem (Law No. 11196/2005)," Journal of technology management \& innovation, vol. 9, no. 4, pp. 53-63, 2014. Available from: http://dx.doi.org/10.4067/s0718 27242014000400004

[7] Sayfieva S.N. The tax burden on the Russian economy. Macroeconomic analysis. - Moscow: LKI - 2010. - 240 p.

[8] M. Kakaulina, "The Tax Burden and Economic Growth in the Far Eastern Regions," Spatial Economics, vol. 2, no. 34, pp. 49-64, 2013. Available at: http://dx.doi.org/10.14530/se.2013.2.049-064

[9] M. Orlova, A. Khafizova, "The tax component of innovative activity assessment in the Russian Federation," Life Science Journal, no. 11, pp. 328-333, 2014. Available at: http://www.lifesciencesite.com/lsj/life1111/052_25757life111114_328_ 333.pdf

[10] U.A. Rumina, A.S. Balandina, and K.A. Bannova, "Evaluating the Effectiveness of Tax Incentives in Order to Create a Modern Tax Mechanism Innovation Development," Procedia - Social and Behavioral Sciences, vol. 166, pp. 156-160, Jan. 2015. Available at: http://dx.doi.org/10.1016/j.sbspro.2014.12.502

[11] Statistics and analysis / Federal Tax Service of Russia. Available at: https://www.nalog.ru/rn77/related_activities/statistics_and_analytics/for $\mathrm{ms} /$

[12] Unified Interdepartmental Statistical Information System (UniSIS), Russia. Available at: http://www.fedstat.ru/indicators/start.do

[13] "Electronic Statistics Textbook," StatSoft, Tulsa, OK. Available at: http://www.statsoft.com/textbook/

[14] T. Hill, P. Lewicki, "Statistics: Methods and Applications," StatSoft, Tulsa, OK, 2007

[15] V. Spitsin, A. Mikhalchuk, L. Spitsina, N. Shabaldina and D Novoseltseva, "Clustering of Russian Regions on Indicators of the Product Innovation Efficiency: Case Subsection DL "Manufacture of Electrical and Optical Equipment"," 26th International-BusinessInformation-Management-Association Conference "Innovation Management And Sustainable Economic Competitive Advantage: From Regional Development To Global Growth", vol. S I - VI, pp. 589-596, Nov. 2015.

[16] V. Spitsin, A. Mikhalchuk, L. Spitsina, N. Shabaldina, D. Novoseltseva, "Comparative Analysis of Economic and Social Results of Foreign and Domestic Firms: Case Russian Electronic Industry" 26th InternationalBusiness-Information-Management-Association Conference "Innovation Management And Sustainable Economic Competitive Advantage: From Regional Development To Global Growth", vol. S I - VI, pp. 769-775, Nov. 2015

[17] Nuzhina I. P. , Yudakhina O. B. , Kotik E. I. , Matyugina E. G. Ecologization of Management Functions as a Factor of Sustainable Development of Construction Industry in Russia // Second International Conference on Economics and Management (ICEM2015): Conference Proceedings, China, May 15-16, 2015. - Lancaster: DEStech Publications Inc., 2015 - p. 414-417

[18] Bannova K.A., Dolgih I.N., Zhdanova A.B., Pokrovskaya N.V. (2015) Developing The Competitive Advantage Of Companies And Regions By The Creation Of Consolidated Groups Of Taxpayers, Innovation Management and Sustainable Economic Competitive Advantage: From Regional Development to Global Growth The 26th IBIMA conference in Madrid. 2015, p. 834-841

[19] Khaperskaya, A. V.; Bannova, K. A.; Musina, S. Z. (2015) The Influence of Corporate Social Responsibility Program on the Economic 
Mechanism as a Whole, International Conference on Economics and Management (ICEM) : MAY 15-16, 390-393

[20] Nikulina I.E., Tarabanovsky A.A. "Monitoring Analysis" and "monitorcriteria" in the system of financial planning of the Autonomous Educational Institution of Higher Professional Education // Fundamental Research, 2009, - № 1. - C. 82-88.

[21] I. P. Nuzhina, O. B. Yudakhina, E. I. Kotik , E. G. Matyugina "Ecologization of Management Functions as a Factor of Sustainable Development of Construction Industry in Russia”, ICEM2015, 2015, pp. 414-417

[22] N. Chistyakova, V. Spitsin, T. Gromova, N. Shabaldina, A. Dudnikova, "Comparative Investment Analysis of Industries Development in Russia and Germany". Proceedings of the 2015 International Conference on Education Reform and Modern Management, Atlantis Press; 2015; Available from: http://dx.doi.org/10.2991/ermm-15.2015.98 